\title{
Gender patterns in academic entrepreneurship
}

\author{
Maria Abreu $^{1}$ - Vadim Grinevich ${ }^{2}$
}

Published online: 21 December 2016

(C) The Author(s) 2016. This article is published with open access at Springerlink.com

\begin{abstract}
Our study analyses the determinants of the gender gap in academic entrepreneurship among UK-based academics from across a wide range of academic disciplines. We focus on spinout activity as a measure of academic entrepreneurship, and explore the relevance of the different explanations for the gender gap. Our analysis is based on a unique survey of UK academics conducted in 2008/2009. The survey provides microdata on over 22,000 academics in the sciences, social sciences, arts and humanities, across all higher education institutions in the UK. Our results show that female academics differ from the male academics in the sample in important ways. Female academics are more likely to be involved in applied research, to hold more junior positions, to work in the health sciences, social sciences, humanities and education, to have less prior experience of running a business, and to feel more ambivalent about research commercialisation. All of these characteristics are correlated with lower rates of spinout activity. Using a nonparametric decomposition analysis, we show that certain combinations of characteristics of male academics have few or no matches to female academics, and these characteristics explain a large proportion of the gender gap.
\end{abstract}

Keywords Academic entrepreneurship - Gender gap · Blinder-Oaxaca · Non-parametric decomposition

JEL Classification $\mathrm{O} 31 \cdot \mathrm{O} 32 \cdot \mathrm{L} 30 \cdot \mathrm{C} 80$

Maria Abreu

ma405@cam.ac.uk

Vadim Grinevich

v.grinevich@soton.ac.uk

1 Department of Land Economy, University of Cambridge, 19 Silver Street, Cambridge CB3 9EP, UK

2 Southampton Business School, University of Southampton, Highfield, Southampton SO17 1BJ, UK 


\section{Introduction}

Academic entrepreneurship, defined as the commercial application of academic research, is an increasingly important aspect of academic life. In most institutions, academic researchers are strongly encouraged (or even required) to disclose their inventions to the university, and to actively participate in the commercialisation of their research findings (Owen-Smith and Powell 2001; Agrawal and Henderson 2002; Murray 2002; Siegel et al. 2003). However, several recent studies have highlighted the existence of a gender gap in academic entrepreneurship. Female academics are less likely to disclose their inventions (Thursby and Thursby 2005), hold a patent (Whittington and Smith-Doerr 2005; Ding et al. 2006) or create a new enterprise based on their research (Rosa and Dawson 2006). This is surprising given that the gender gap in other measures of academic productivity, such as publishing, is closing (Xie and Shauman 2003).

A number of possible explanations have been identified, including supply-side factors such as lack of industry experience, greater reliance of institutional support, lower levels of seniority and choice of research area by female academics, and demand-side factors such as lower visibility, exclusion from networks and gender discounting (Murray and Graham 2007; Stephan and El-Ganainy 2007). The relevance of some of these factors, particularly those relating to networks and lack of experience, have been confirmed by female academics as part of qualitative case-study interviews (Murray and Graham 2007). Moreover, there is significant quantitative evidence to show that personal and institutional characteristics, such as level of seniority, academic field and degree of institutional support, have an effect on academic entrepreneurship at all stages of the process (Stephan et al. 2007; Haeussler and Colyvas 2011). In particular, Colyvas et al. (2012) find that once a range of personal and institutional characteristics are accounted for, there is no further gender gap in the likelihood of disclosure of inventions, or in the likelihood that disclosures are converted into licenses.

Running through the discussion in the literature are two issues of significance. First, there is now substantial evidence to suggest that rates of academic entrepreneurship are greater in disciplines and fields which have a lower representation of female academics (Rosa and Dawson 2006). Similarly, academic entrepreneurship is greater among senior academics with wide-ranging networks and experience of commercialisation, and an overwhelmingly large proportion of those academics are male (Stephan and El-Ganainy 2007). This raises the (as yet unresolved) question of whether female academics with lower propensities to engage in entrepreneurship are self-selecting into disciplines and career paths that further exclude them from entrepreneurial opportunities.

Second, there is limited evidence on the entrepreneurial intentions and outcomes for academics in disciplines other than the engineering, medicine and the physical sciences. An understanding of the commercialisation activities of academics in the arts, social sciences and humanities is key to explaining the choices of female academics, and their resulting career outcomes. For instance, academics in the creative arts are widely engaged in both consulting and the creation of enterprises based on academic research (Abreu and Grinevich 2014), but it is unclear how this affects the overall gender gap in academic entrepreneurship.

This study aims to address both of these gaps in the literature by analysing the entrepreneurial activities of male and female academics based at a wide range of academic institutions and from a broad range of disciplines. We focus particularly on understanding why the choices of male and female academics differ, and use a non-parametric matching 
procedure to analyse whether the entrepreneurial outcomes are different for male and female academics who are otherwise very similar in terms of their personal and institutional characteristics. We use the creation of enterprises based on university research (or "spinouts") as our measure of academic entrepreneurship, as this is the most comparable measure across academic disciplines, and provides a clear parallel to measures of entrepreneurship in the wider literature.

The remainder of the paper is organised as follows. Section 2 provides an overview of the literature on the gender gap in academic entrepreneurship, and the possible explanations that have been advanced in the literature. Section 3 describes our data and methods. Section 4 provides descriptive evidence on the gender gap and the different explanations identified in the literature. Section 5 presents the evidence on the issue of self-selection. Section 6 concludes and discusses policy implications.

\section{Is there a gender gap in academic entrepreneurship?}

A large literature has explored the existence of a gender gap in scientific careers, both within and outside academia. Women are less likely than men to study science at university, less likely to hold academic positions in the sciences, and significantly less likely to hold senior faculty positions (Xie and Shauman 2003). Of the possible explanations for these disparities, the most widely-held theory is the so-called "leaky pipeline" model, which argues that women drop out of the scientific career path at various points in their life, such as when choosing which subjects to study in school, transitioning to higher education, continuing on to graduate school, applying for faculty positions, and achieving tenure. For instance, in a wide-ranging study of the gender gap in science, Xie and Shauman (2003) find that most of the early-stage gender gaps (such as the proportion of girls choosing science subjects at high school) have closed over time, but that self-selection by women into specific career paths that are seen as more compatible with family life has persisted. This includes opting to specialise in fields that are seen as less competitive and more amenable to flexible working, and for which there are fewer geographical constraints (particularly for women with school-age children). These choices are also reflected in measures of academic productivity, such as publishing. For instance, a number of studies have found that female academics publish less often than their male counterparts, although there is evidence to suggest that this gap has decreased over time (Cole and Zuckerman 1984; Long 1992; Thursby and Thursby 2005), and that while female academics publish fewer articles, their publications have greater impact, as measured using citations (Long 1992).

The academic gender gap is also evident in a variety of measures of research commercialisation, from early-stage intentions, to patenting, licensing and the creation of spinouts. Focusing on the early (or "ex-ante") stage of the process, Goel et al. (2015) use data from a survey of German scientists working at Max Planck institutes, and find that female academics have significantly lower propensities towards entrepreneurship, defined as a lower perceived attractiveness of creating a spinout. Similarly, using data on invention disclosures, Colyvas et al. (2012) find that US male faculty members are slightly more likely to report an invention (37 vs. $32 \%$ for women), and significantly more likely to report multiple inventions to their institution's Technology Transfer Office (TTO) than their female colleagues. This corroborates earlier evidence by Thursby and Thursby (2005), which shows that despite few differences in publications by gender, the probability 
of disclosure of an invention by a male academic is $43 \%$ higher than that of an individual academic.

Similar results have been found in the context of patenting, with significantly fewer female academics holding patents, relative to their male counterparts. For instance, using data US-based academic life scientists, Ding et al. (2006) find that $6 \%$ of women in the sample hold patents, versus $13 \%$ of the men. The likelihood that an individual academic has not patented up to a given year of their tenure is higher for women at all career stages, and the gender gap increases over time (Ding et al. 2006). Interesting, the academic context appears to exacerbate this gender gap: Whittington and Smith-Doerr (2005) show that US male scientists in industry patent 1.4 times as much as female scientists, but the gender gap is 2.3 times in academia. As with publishing, there is no difference in the quality of the patents (as measured by patent citations) of male and female scientists (Whittington and Smith-Doerr 2005). Similar findings have been reported for other measures of academic entrepreneurship, such as spinouts. Although based on a relatively small sample, Rosa and Dawson (2006) find that only $12 \%$ of the spinouts in their UK sample were founded by women. Female academics also tend to engage in fewer types of commercialisation activity (Haeussler and Colyvas 2011).

\section{Disentangling the explanations}

While the presence of a significant gender gap in academic entrepreneurship is well documented, there is still considerable controversy over the precise reasons for this gap, which in turn has implications for the appropriate policy responses. A number of studies have investigated whether the gender gap remains once individual and institutional factors are accounted for. This would imply that, although a gender gap in outcomes exists, we are able to explain it with reference to constraints, and resulting constrained choices, affecting female academics. For instance, Colyvas et al. (2012) find that gender has no significant effect on the likelihood of disclosing inventions once individual characteristics (such as academic rank, publishing activity, and external research funding) have been accounted for. Similarly, the authors find no effect of gender on the likelihood that a disclosure becomes a license (although there is a significant gender gap in the volume of disclosures). The authors conclude that the observed gender gap is due to "occupational and resource factors, reflecting the volume of engagement, rather than discrete proclivity to commercialize or the level of success in doing so" (Colyvas et al. 2012, p. 486).

However, an unresolved issue that remains is the extent to which female academics are responding to these constraints by modifying their behaviour, and whether their actions would be different if their circumstances changed. This warrants a closer look at the potential factors that could affect their engagement with entrepreneurship. Several studies have discussed these factors in detail, and it is helpful to classify them into supply- and demand-side explanations, following Stephan and El-Ganainy (2007) and Murray and Graham (2007). The supply-side explanations are those relating to the decision by the academic to engage in entrepreneurial activities, and the resources available to do this (skills, networks, interest), while the demand-side explanations relate to discrimination and lack of opportunities.

On the supply side, one important factor that affects entrepreneurship is the research area or academic field. As is well documented in the literature, some research areas are more conducive to commercialisation than others. For instance, research in the life 
sciences lends itself readily to commercial exploitation since fundamental research and applied work tend to co-evolve (Murray 2002; Stephan et al. 2007). The same is true for other areas in science which primarily involve use-inspired basic research, that is, basic research that is also inspired by considerations of use (Stokes 1997). Conventional measures of academic entrepreneurship such as disclosures, patents, licences and spinouts are often lower in the arts and humanities, partly because copyright and trademarks are more common forms of intellectual property protection in these disciplines, and partly because external engagement in the arts and humanities is generally based on more informal types of activities such as giving public lectures and organising exhibitions (Abreu and Grinevich 2013, 2014). If women are over-represented in these disciplines (either through choice or due to discrimination), and/or under-represented in areas of the sciences that are more conducive to commercialisation, then this might help to explain the gender gap in the more traditional measures of academic entrepreneurship. ${ }^{1}$

A second supply-side explanation, which is also partly a demand-side explanation (in terms of the issues of visibility that it raises), is the notion that women tend to occupy less senior positions in academia, and may therefore choose to focus on advancing their academic careers, rather than on engaging in entrepreneurial activities. This is particularly true if women are constrained by family obligations that place severe pressures on their time (Ding et al. 2006; Rosa and Dawson 2006). ${ }^{2}$ Family circumstances, such as marital status, career breaks to look after children or elderly parents, and tied moves concerning the job of their partner, can have a significant effect on female entrepreneurship (Rosa and Dawson 2006). A related issue is the importance of previous commercial or business experience in encouraging future entrepreneurial behaviour. Female academics tend to have lower levels of exposure to industry and business, and therefore rely more heavily on the TTO (Stephan and El-Ganainy 2007). A number of studies have found support for the latter hypothesis, for instance, in case study interviews of female life-scientist, Ding et al. (2006) and Murray and Graham (2007) find that women are more likely to rely on the TTO for industry contacts, advice and encouragement. Similarly, Rosa and Dawson (2006) find that women are more likely to cite the shortcomings of the TTO as an obstacle to commercialisation. In a set of regressions to explain the propensity towards entrepreneurship, Goel et al. (2015) find that previous industry experience and "TTO needed for commercialisation" had larger predicted effects for female than for male academics. Being based at a larger and more prestigious university could mitigate some of the negative impacts of a lack of visibility to external partners, since larger, research-intensive institutions tend to have better established and more experienced TTOs (Siegel et al. 2007).

A final set of supply-side explanations relate to psychological factors. There is evidence to suggest that women tend to be more risk-averse than men in the context of business or

\footnotetext{
1 The importance of use-inspired basic research for commercialisation may be greater in some disciplines (such as the life sciences) than in others (such as the social sciences). This may be the case if, for instance, the dominant mode of academic entrepreneurship in the social sciences is consultancy work, which is likely to follow more readily from applied research, rather than from use-inspired basic research. In order to allow for these variations, we control for both the academic discipline and the type of research in our empirical analysis.

2 A related factor, often considered in the wider entrepreneurship literature, is the age of the potential entrepreneur. Life cycle theories suggest that early career researchers focus on research and teaching in order to gain tenure, while older, more senior, academics are less constrained and have more time to devote to commercialisation (Carayol 2007; Levin and Stephan 1991; Link et al. 2007; Stephan et al. 2007). Older academics are also more likely to have the wide-ranging networks required to identify and develop entrepreneurial opportunities. This factor is closely related to academic position (or seniority), as shown by the correlation matrix in Table 19 (in the Appendix).
} 
financial ventures (Eckel and Grossman 2008; Croson and Gneezy 2009; Borghans et al. 2009). This may lead them to avoid potentially riskier entrepreneurial activities such as spinouts, and instead opt for less formal methods of commercialisation (such as consultancy work), or to avoid entrepreneurial activities altogether. Related to this is the finding that women tend to dislike competitive behaviour, and therefore avoid activities perceived to involve competition with their peers (Murray and Graham 2007). The literature has also found that women are less likely to actively seek to "sell" their research, and numerous studies document that female academics believe they are left out of entrepreneurial ventures due to "not being asked" (Rosa and Dawson 2006; Murray and Graham 2007). In addition, there is evidence that women feel more ambivalent towards the ethics of the commercialisation process (Murray and Graham 2007), although this factor may be changing as more $\mathrm{PhD}$ students and junior faculty are exposed to commercial links from the outset of their careers (Ding et al. 2006).

On the demand side, the explanations revolve around the level of interest of external partners in the entrepreneurial ventures of female academics. Given that fewer female academics have previous commercial experience (as discussed above), we might expect that their networks include fewer contacts within industry or business, which might make it more difficult to "sell" a patent or business idea. Female academics also tend to have fewer $\mathrm{PhD}$ students, and are therefore less likely to become involved in entrepreneurial ventures through requests from former students (Murray 2004). The lack of wide-ranging networks been found in qualitative research to be one of the biggest constraints to female entrepreneurship (Murray 2004; Ding et al. 2006). In addition, women may face difficulties in raising finance for their ventures, partly because their lower academic rank makes them less visible to potential partners (Rosa and Dawson 2006), and partly due to discrimination, since venture capitalists tend to be male, and may have a "higher comfort level with men than with women and thus contribute to the gender gap" (Stephan and El-Ganainy 2007).

As discussed above, a key unresolved question in the literature is the extent to which these findings are affected by selection bias. More precisely, whether the gender gap would close if female academics had the same attributes and institutional contexts as their male counterparts. In other words, the issue is not simply that female academics have a lower rate of engagement in absolute terms (the constant in the regression). It is that their endowments (the values of the explanatory variables) are different, and the effects of those endowments on academic entrepreneurship (the coefficients) are also different. In fact, there are usually very few (or even no) female academics with precisely the same attributes as their male counterparts, such as working in a top research university, in a highlycompetitive scientific sub-field, holding a senior position, with previous experience of entrepreneurship. While existing studies have accounted for differences in the attributes by including a wide range of explanatory variables (to account for differences in the endowments), or by running separate regressions for male and female academics (to account for differences in both the endowments and their effects), there are very few studies that have attempted to address the issue of selection bias. A notable exception, although not in a quantitative context, is Murray and Graham (2007), who interviewed all female academics in the life sciences working in "Big School", a prestigious university, and a matched sample of male academics for comparison purposes. Crucially, the male interviewees were identified by asking the female interviewees to provide details of "one or more of their male peers within Big School" (Murray and Graham 2007). Although the resulting sample is not random, it has the advantage of ensuring (in as much as possible) that the male and female samples are comparable in terms of the attributes. There are no 
similar approaches based on large-scale, quantitative studies, and our paper aims to fill this gap.

\section{Data and methods}

\subsection{Data sources and limitations}

Our unit of analysis is the individual academic, and our data originates from a survey conducted in 2008-2009 as part of a wider project on the knowledge-exchange activities of UK academics. The survey was administered using an online web-survey tool, and was sent to all academics in the UK who were publicly listed on their institution's website in 2008 , resulting in a sampling frame of 126,120 academics from across all UK higher education institutions and disciplines. ${ }^{3}$ The achieved sample was 22,556, for an overall response rate of $18 \%$. The survey included questions on a wide range of entrepreneurial activities (including informal activities), personal characteristics, the nature of the respondent's teaching and research, questions about the culture and ethics of academic entrepreneurship, and the geographical scope of the respondent's entrepreneurial activities. The questions in the survey refer to the 3-year period prior to the survey (i.e., to 2005-2008).

Due to the method used in constructing the sampling frame, which involved collecting names and contact details from university websites, it is possible that the survey undersampled junior academics (in particular, research assistants and teaching assistants), since they are less likely to be listed on department websites, given their relatively short contracts. It is also possible that senior academics were more likely to respond to the survey (given their greater experience in entrepreneurial activities), although we are unable to verify this since the sampling frame does not contain personal details such as academic position. ${ }^{4}$ Our achieved sample includes a higher proportion of professors, readers and senior lecturers (the most senior positions), and a lower proportion of lecturers and research associates or assistants (the most junior positions), relative to the population (see Table 13 in Appendix for details). In addition, the male/female gender ratio among the professors in our sample is higher than it is in the population, while there is no difference in the gender ratio for other, more junior, positions (Table 14 in Appendix). It is likely that academics with little involvement in entrepreneurial activities were less likely to complete the survey, despite our best efforts, including several statements, both on the survey and on the project website, urging them to do so. Since female academics are less likely to be involved in entrepreneurial activities, it may be that female academics not involved in entrepreneurial activities were less likely to complete the survey and that our sample therefore includes a higher than expected number of female entrepreneurs. Our findings showing the existence of a significant gender gap are therefore more likely to understate the scale of the problem, than to overstate it.

Similarly, the survey slightly oversampled academics in the disciplines more likely to be involved in entrepreneurial activities (such as the health sciences, engineering and the physical sciences, and business and media), and undersampled academics in disciplines

\footnotetext{
3 A small number of paper questionnaires were also distributed to those who requested it, see Abreu et al. (2009) for further details.

${ }^{4}$ Collecting personal information in addition to contact details would have been prohibitively time-consuming, given the numbers involved and the lack of information provided on some university websites.
} 
with low levels of engagement (such as the social sciences, humanities and education). Again this is probably due to lower response rates by academics who are not involved in entrepreneurial activities (Table 15 in Appendix). The male/female gender ratio is also higher in the sample than in the population in these disciplines, suggesting that we may be underestimating the gender gap in the most entrepreneurial research fields (Table 16 in Appendix).

In order to ensure a broadly comparable sample, we exclude from the analysis academics who reported that they were not involved in either teaching or research activities (these are mainly senior university administrators and those on secondment to external organisations), resulting in a sample of 22,300 individuals, based at $150 \mathrm{UK}$ higher education institutions. ${ }^{5}$ We distinguish between the 24 research-intensive universities who form part of the Russell Group (referred to as "top research university" in the analysis), and the remaining 126 institutions.

\subsection{Methods}

Our analysis consists of four stages. First, we use a set of descriptive statistics to give a first indication as to whether the gender patterns of academic entrepreneurship are affected by the factors identified in the literature (and discussed in Sect. 2). We focus in particular on the type of entrepreneurial activity undertaken (patenting, licensing, spinouts and consultancy work), and consider their correlation with personal characteristics such as type of research, academic discipline, level of seniority, ethical views on entrepreneurship, previous experience, and the level of institutional support. We also provide preliminary evidence to show that a selection bias mechanism might be at work. The descriptive analysis also shows the results of a test of equality of proportions for each gender difference considered.

Second, we estimate two probit models to quantify the extent of the gender gap after controlling for a range of explanatory variables. Our outcome of interest for this part of the analysis is spinout activity, or more precisely, whether the individual has been involved in the creation of an enterprise based on his/her research in the past 3 years. ${ }^{6}$ The first model includes only a female dummy variable, the coefficient of which is equivalent to the gender gap measured as the difference between the rate of male and female spinout activity. The second model includes a female dummy variable, and a number of explanatory variables identified in the literature as contributing to the academic entrepreneurship gender gap. The second model is equivalent to the approach used in Colyvas et al. (2012), who find that once all relevant factors are included in the regression, there is no longer a statistically significant gender gap in academic entrepreneurship (see the discussion in Sect. 3 for more details).

\footnotetext{
5 The number of observations is lower in the Blinder-Oaxaca and Nopo decomposition analyses, due to item non-response (18,975 individuals).

${ }^{6}$ We chose this outcome variable as the measure of academic entrepreneurship that is most comparable across the sciences, social sciences, humanities and the arts. Other outcome variables; such as disclosures, patenting and licensing are prevalent in the sciences but almost unheard of in the social sciences and the arts, while public exhibitions and copyright protection are common in the arts, but mostly irrelevant for the sciences (Abreu and Grinevich 2013). Consultancy is another option we considered, but what is meant by consultancy differs widely across institutions and research groups, while the creation of spinouts is a relatively clear and quantifiable activity. Another advantage is that it provides a clear link to the wider entrepreneurship literature.
} 
Third, we use a Blinder-Oaxaca decomposition approach to disaggregate the differences in academic entrepreneurship between male and female academics into a part that is explained by differences in the endowments, and a second part that is explained by differences in the coefficients (Blinder 1973; Oaxaca 1973). Our outcome variable for this part of the analysis is also spinout activity. The Blinder-Oaxaca decomposition starts from the premise that there are two groups, Group 1 (the reference group, with the highest outcome), and Group 2. In our case, Group 1 is comprised of male academics, and Group 2 of female academics. We use the "two-fold" Blinder-Oaxaca decomposition, which allows us to separate the mean difference between the two groups $D$ into two components:

$$
D=E+C
$$

where $E$ is the part that is explained by differences in the endowments (explanatory variables), and $\mathrm{C}$ is the part that is explained by differences in the coefficients. Intuitively, $E$ captures the expected change in the mean outcome of female academics, if female academics had the attributes of the male academics in the sample, whereas $C$ shows the expected change in the mean outcome of female academics, if female academics had the coefficients of the male academics in the sample. We are thus able to analyse whether it is the systematic differences in the attributes of female academics that explain the gender gap, or whether what matters is how those attributes translate into entrepreneurial outcomes (or both).

Finally, we extend the Blinder-Oaxaca decomposition to control for the possibility that there may be combinations of attributes for which it is possible to find male academics in the sample, but not female academics. Failing to control for these differences (henceforth the problem of "differences in the supports"), which may be due to choices made throughout academic careers, leads to misspecification, and in the context of the BlinderOaxaca decomposition, tends to overestimate the component of the gap that is due to differences in the coefficients. We control for this misspecification problem using a nonparametric technique developed by Nopo (2008). Intuitively, the gap is now disaggregated into four components:

$$
D=M+X+F+D_{0}
$$

where $D$ is the gender gap as before; $M$ is the part explained by differences between male academics who have characteristics that cannot be matched to female characteristics, and those who have characteristics that can be matched; $X$ is the part explained by differences in the distribution of male and female characteristics over the matched sample (corresponds to $E$ in the Blinder-Oaxaca decomposition, under the assumption of no selection bias); $F$ is the part explained by differences between females who have characteristics that can be matched to male characteristics, and those who have characteristics that cannot be matched; and $D_{O}$ is the unexplained part (corresponding to $C$ in the Blinder-Oaxaca decomposition). The matching process works as follows (Ñopo 2008, p. 293):

(a) Select one female academic from the sample.

(b) Select all males that have the same characteristics as the female selected in (a).

(c) Using all the individuals selected in (b), construct a synthetic individual whose rate of spinout activity is the average of all of these individuals, and match him to the original female academic.

(d) Add the observations for both individuals (the female academic and the synthetic male academic) to their respective samples of matched individuals.

(e) Repeat steps (a)-(d) until all of the original sample of female academics has been exhausted. 
This non-parametric procedure allows us to establish whether the gender gap is due to differences in the endowments between male and female academics with attributes that can be matched, differences in the coefficients (the unexplained part), or differences due to the fact that male academics have attributes that are highly correlated with academic entrepreneurship, but which are rarely found among female academics (and vice versa). The choice of characteristics for matching is a subjective one; choosing a greater number of characteristics results in a closer match, but restricts the number of male and female academics who fall into the matched sample, and therefore reduces the estimate of $\mathrm{X}$, the proportion of the gap that can be explained by differences in the male and female characteristics over the matched sample. For simplicity, our matching variables are the same variables used as explanatory variables in the Blinder-Oaxaca decomposition.

\subsection{Variables included in the analysis}

As discussed in Sect. 4.2, the dependent variable used in the decomposition analysis is spinout activity, defined as whether an academic has been involved in the creation of an enterprise based on his or her research. In the descriptive analysis we also consider several other types of entrepreneurial activity, including patenting, licensing and consultancy, all of which are defined as whether an activity of a particular type occurred in the 3 years prior to the survey date. In addition, we consider several more informal activities, including sitting on advisory boards, giving public lectures, engaging in contract research, providing informal advice and participating in exhibitions, all of which are entrepreneurial in nature.

Throughout the analysis, we use a set of explanatory variables that aim to capture the potential explanations for gender bias advanced in the literature, as discussed in Sect. 3. A first set of explanatory variables relate to the personal characteristics of the respondent that have been hypothesised to affect the supply of entrepreneurship, and these include academic position (professor, reader/senior lecturer, lecturer, research fellow, research assistant), type of research based on the Stokes (1997) classification (basic research, userinspired research, applied research, other), academic discipline (health sciences, biological sciences, engineering and physical sciences, social sciences, business and media, humanities, creative arts, or education), whether the respondent is based at Russell Group research-intensive university (top research university), whether he/she has experience of previously starting or managing a small business (business experience), and whether he/she participates in networks that include potential external partners (network participant). ${ }^{7}$

\footnotetext{
${ }^{7}$ Other variables such as household characteristics (marital status, the presence of children, whether a close relative owns a small business) are also relevant, but are unfortunately unavailable in our data. Another variable that is frequently considered in the entrepreneurship literature is age. It is likely that the effect of age on the entrepreneurship gender gap is similar to that of the level of seniority, since female academics are particularly constrained in their visibility and access to networks when they are young and in junior positions. The survey provides data on the age group of the respondent (under 30, 30-39, 40-49, 50 and over), but there is a higher than average incidence of item non-response for this variable. This variable is strongly correlated with academic position, as shown in Table 19 in Appendix, but conceptually the academic position variable is more relevant in explaining academic entrepreneurship (since it is seniority, rather than just age, that determines the ability to identify and exploit entrepreneurial opportunities). We include age-group dummies in probit regressions for female and male entrepreneurship, and the results show that only the "under 30" variable is statistically significant (and negative), and only for male academics. Given the lower sample size for this variable, the high correlation of the academic position and age dummies, and the conceptual similarity of the arguments for academic position and age, we ultimately decided to include only academic position in the analysis that follows. The results for the other variables do not change if the age variable is included (details are available upon request).
} 
We also include a number of variables relating to the perceived constraints and ethi$\mathrm{cal} /$ moral views of research commercialisation, identified as part of the psychological explanations for the supply of entrepreneurial activities. These include whether the individual perceives that they are constrained in by a lack of time to fulfill all university roles (lack of time), by difficulty in finding potential external partners (no partners), and by a lack of interest from external organisations (lack of interest). We also include two variables that capture the views of each individual with respect to the ethics and morality of academic entrepreneurship. They indicate whether the individual feels that commercialization has been taken too far (too far), and whether an individual feels that universities are doing too little to meet the needs of business and industry (too little). ${ }^{8} \mathrm{~A}$ list of the variables included in the analysis, the relevant survey questions, and details of any additional data manipulations used to construct them, can be found in Table 17 in Appendix.9

Our analysis is limited to the supply side explanations, since we only capture the determinants and constraints reported by the individual academics, and do not have access to information on their potential or actual external partners. However, a few of the factors, such as the level of seniority, and participation in networks that also feature non-academic partners, can shed some light on the demand side constraints faced by female academics. Likewise, the perception of a lack of interest from external partners may reflect both supply- and demand-side explanations. We discuss these issues in more detail in the next section.

\section{Quantifying the gender gap}

We start the analysis by quantifying the gender gap in academic entrepreneurship, using descriptive statistics. As shown in Table 1, the gender gap among UK academics is fairly large and statistically significant, particularly for patenting $(6.1 \%)$ and consultancy work $(6.8 \%)$. It is also fairly significant for licensing (3.9\%) and spinouts (3.2\%). These numbers are generally in keeping with those found in earlier studies. A gender gap is also apparent for more informal measures of entrepreneurship, such as sitting on advisory boards (7.3\%), contract research $(5.6 \%)$, giving public lectures $(6.3 \%)$, and providing informal advice to non-academic partners $(5.3 \%)$. In keeping with our discussion in Sect. 2, it is likely that

Table 1 Gender gap by type of activity (\% involved in each activity)

\begin{tabular}{lclll}
\hline & Male & Female & Difference & Z-value \\
\hline Patenting & 9.6 & 3.5 & $6.1^{* * *}$ & 15.92 \\
Licensing & 6.3 & 2.4 & $3.9^{* * *}$ & 12.52 \\
Spinouts & 4.8 & 1.6 & $3.2^{* * *}$ & 11.91 \\
Consultancy & 16.6 & 9.8 & $6.8^{* * *}$ & 13.24 \\
\hline
\end{tabular}

Data from the Cambridge Centre for Business Research Survey of Knowledge Exchange Activity by United Kingdom Academics, 2005-2009 (see Abreu et al. 2009 for details). The Z-value corresponds to a difference in proportions test

${ }^{\dagger}$ Omitted category; $* * *$ significant at $1 \%$; ** significant at $5 \%$; $*$ significant at $1 \%$

\footnotetext{
${ }^{8}$ All of these explanatory variables are dummy variables, and equal to one if true, and to zero otherwise. See Table 17 in Appendix for details.

9 Table 18 in Appendix shows the correlation matrix for all the dependent and explanatory variables used in the analysis.
} 
Table 2 Informal and non-commercial activities (\% of all respondents)

\begin{tabular}{llllr}
\hline & Male & Female & Difference & Z-value \\
\hline Sitting on advisory boards & 40.0 & 32.7 & $7.3^{* * *}$ & 10.64 \\
Giving public lectures & 40.4 & 34.1 & $6.3^{* * *}$ & 9.27 \\
Contract research & 38.3 & 32.7 & $5.6^{* * *}$ & 8.11 \\
Giving informal advice & 58.6 & 53.3 & $0.3^{* * *}$ & 7.59 \\
Participating in exhibitions & 14.8 & 13.9 & 1.87 \\
\hline
\end{tabular}

Data from the Cambridge Centre for Business Research Survey of Knowledge Exchange Activity by United Kingdom Academics, 2005-2009 (see Abreu et al. 2009 for details). The Z-value corresponds to a difference in proportions test

$\dagger$ Omitted category; $* * *$ significant at $1 \%$; ** significant at $5 \%$; $*$ significant at $1 \%$

Table 3 Type of research (\% who describe their research as...)

\begin{tabular}{lccrr}
\hline & Male & Female & Difference & Z-value \\
\hline Basic research & 29.5 & 21.5 & $8.0^{* * *}$ & 12.92 \\
Use-inspired basic research & 29.3 & 27.4 & $1.9 * * *$ & 3.04 \\
Applied research & 38.0 & 46.4 & $-8.4 * * *$ & -12.16 \\
Other type of research & 3.3 & 4.8 & $-1.5^{* * *}$ & -5.59 \\
\hline
\end{tabular}

Data from the Cambridge Centre for Business Research Survey of Knowledge Exchange Activity by United Kingdom Academics, 2005-2009 (see Abreu et al. 2009 for details). The Z-value corresponds to a difference in proportions test

$\dagger$ Omitted category; $* * *$ significant at $1 \%$; ** significant at $5 \%$; $*$ significant at $1 \%$

less formal activities that are not usually channelled through the TTO favour male academics, who tend to have wider networks and tend to be more visible to external organisations due to their greater seniority levels and previous involvement in commercial ventures. The only measure without a statistically significant gender gap is participating in public exhibitions $(0.9 \%)$, which tends to be the preserve of academics in the creative arts (Table 2).

We next explore the evidence relating to the theories discussed in Sect. 2. One of the most salient findings in the literature is the relationship between the type of research undertaken and the gender gap. Some academic disciplines and sub-fields, such as the life sciences, lend themselves readily to commercialisation, since the research is both fundamental, but also inspired by considerations of use. If female academics are less likely to be involved in this type of research, and more likely to concentrate in disciplines with little tradition of entrepreneurship, then this would go some way towards explaining the entrepreneurship gender gap. Table 3 illustrates this issue, by showing the percentage of male and female academics who describe their research as (a) basic, (b) use-inspired basic, (c) applied, or (d) other. ${ }^{10}$ These categories are based on Stokes (1997), who argues that

\footnotetext{
10 The "other" category includes all those who chose the option "none of the above applies to my research", and is likely to include those who are involved in, for instance, practice-led research, action research, or where the research is an equal mix of the other types (i.e., there is no dominant form of research). Less than $4 \%$ of the respondents selected this category.
} 
Table 4 Spinout activity by discipline (\% of faculty that is female, \% involved in spinouts)

\begin{tabular}{lllllr}
\hline & $\begin{array}{l}\text { Female } \\
\text { faculty }\end{array}$ & $\begin{array}{l}\text { Female } \\
\text { entrepreneurs }\end{array}$ & $\begin{array}{l}\text { Male } \\
\text { entrepreneurs }\end{array}$ & Difference & $\begin{array}{l}\text { Z- } \\
\text { value }\end{array}$ \\
\hline Health sciences & 54.8 & 1.2 & 5.0 & $3.8^{* * *}$ & 6.61 \\
Biological sciences & 37.3 & 2.0 & 4.7 & $2.7^{* * *}$ & 3.09 \\
$\begin{array}{l}\text { Eng. and physical } \\
\quad \text { sciences }\end{array}$ & 19.5 & 3.2 & 7.9 & $4.7^{* * *}$ & 4.68 \\
Social sciences & 42.3 & 1.4 & 1.6 & 0.2 & 0.51 \\
Business and media & 35.1 & 3.2 & 6.5 & $3.3^{* *}$ & 2.54 \\
Humanities & 45.8 & 0.2 & 1.1 & $0.9^{* *}$ & 2.53 \\
Creative arts & 39.3 & 3.1 & 6.3 & $3.2^{* *}$ & 2.20 \\
Education & 55.2 & 0.6 & 2.7 & $2.1^{* * *}$ & 3.02 \\
All disciplines & 39.8 & 1.6 & 4.8 & $3.2^{* * *}$ & 11.91 \\
\hline
\end{tabular}

Data from the Cambridge Centre for Business Research Survey of Knowledge Exchange Activity by United Kingdom Academics, 2005-2009 (see Abreu et al. 2009 for details). The Z-value corresponds to a difference in proportions test

basic and use-inspired research are conducive to the most lucrative and wide-ranging commercial ventures, while applied research is often too narrowly defined to lead to substantial commercial activity. As shown in Table 3, female academics are under-represented in both basic and use-inspired basic research, and over-represented in applied research, suggesting that they are under-represented in the research activities that the literature has found are more likely to result in successful commercialisation, although this result may not necessarily hold for all academic disciplines. ${ }^{11}$

Similarly, Table 4 shows that female academics are more likely to work in disciplines with low overall rates of spinout activity, such as the social sciences, humanities and education (the health sciences are an exception), and less likely to work in engineering, the physical sciences and biological sciences, which have high rates of spinout activity. Interestingly, the gender gap tends to be greater in disciplines with higher spinout activity, such as the health sciences, engineering and the physical sciences, business and media, and the creative arts. This suggests that women are both under-represented in high-entrepreneurship disciplines, and are less likely to be involved in academic entrepreneurship even if they are in the "right" disciplines. It is also in keeping with research showing that the majority of business start-ups by women are in sectors with high rates of female employment, and that women are less likely to start a new business in non-traditional sectors (Rosa and Dawson 2006).

We also find evidence for several of the theories discussed in Sect. 2 which highlight the constraints faced by female academics. As shown in Table 5, women are significantly less likely to be full professors, and are over-represented in all other (lower rank) academic positions. We would expect this to lead to lower rates of spinout activity, as professors are the most visible faculty members in academia, with the widest networks and greatest recognition among potential industrial and business partners. However, we also find that, even if female academics have the rank of professor, they are less likely than their male counterparts to be involved in entrepreneurial activities $(2.8 \%$ of female professors are

11 As discussed in Sect. 3, applied research may be more conducive to academic entrepreneurship in disciplines and research areas where consultancy is the most likely approach. 
Table 5 Seniority (\% male/female faculty in each rank; \% involved in spinouts)

\begin{tabular}{lllllll}
\hline & $\begin{array}{l}\text { Male faculty } \\
\text { by rank }\end{array}$ & $\begin{array}{l}\text { Female faculty } \\
\text { by rank }\end{array}$ & $\begin{array}{l}\text { Male } \\
\text { entrepreneurs }\end{array}$ & $\begin{array}{l}\text { Female } \\
\text { entrepreneurs }\end{array}$ & $\begin{array}{l}\text { Difference } \\
\text { Z- } \\
\text { value }\end{array}$ \\
\hline $\begin{array}{l}\text { Professor } \\
\text { Reader or senior }\end{array}$ & 27.0 & 11.7 & 7.8 & 2.8 & $5.0^{* * *}$ & 5.32 \\
$\quad \begin{array}{l}\text { lecturer } \\
\text { Lecturer }\end{array}$ & 21.3 & 33.0 & 4.4 & 2.0 & $2.4^{* * *}$ & 5.17 \\
$\begin{array}{l}\text { Research fellow } \\
\text { Research }\end{array}$ & 15.4 & 28.8 & 3.1 & 1.1 & $2.0^{* * *}$ & 4.53 \\
$\quad$ assistant & 3.5 & 20.7 & 3.4 & 1.0 & $2.4^{* * *}$ & 4.72 \\
\hline
\end{tabular}

Data from the Cambridge Centre for Business Research Survey of Knowledge Exchange Activity by United Kingdom Academics, 2005-2009 (see Abreu et al. 2009 for details). The Z-value corresponds to a difference in proportions test

Table 6 Personal and institutional constraints to academic entrepreneurship (\% of all respondents)

\begin{tabular}{|c|c|c|c|c|}
\hline & Male & Female & Difference & $\begin{array}{l}\mathrm{Z} \text { - } \\
\text { value }\end{array}$ \\
\hline Lack of time to fulfil all university roles & 59.7 & 62.0 & $-2.3 * * *$ & -3.35 \\
\hline Difficulty in identifying partners & 22.1 & 15.5 & $6.6 * * *$ & 12.14 \\
\hline Lack of interest by external organisations & 7.2 & 5.4 & $1.8 * * *$ & 5.51 \\
\hline Bureaucracy and inflexibility of administrators in own institution & 27.3 & 24.3 & $3.0 * * *$ & 4.94 \\
\hline $\begin{array}{l}\text { Poor marketing, technical or negotiation skills of administrators in } \\
\text { own institution }\end{array}$ & 15.5 & 12.7 & $2.8 * * *$ & 5.76 \\
\hline $\begin{array}{l}\text { Insufficient resources devoted by own institution to activities with } \\
\text { external partners }\end{array}$ & 20.7 & 23.4 & $-2.7 * * *$ & -4.69 \\
\hline
\end{tabular}

Data from the Cambridge Centre for Business Research Survey of Knowledge Exchange Activity by United Kingdom Academics, 2005-2009 (see Abreu et al. 2009 for details). The Z-value corresponds to a difference in proportions test

involved in spinouts, compared to $7.8 \%$ of male professors). This is partly due to the other constraints faced by female academics (such as time pressures and lack of business experience), and partly due to the uneven research field and subject mix, with a larger proportion of female professors being in academic disciplines such as the humanities and education which have lower overall rates of entrepreneurial activity.

Female academics are, given their lower ranks and lower levels of previous experience, ${ }^{12}$ more likely to rely on institutional support provided by the TTO. As illustrated in Table 6, while male academics are more likely to be disparaging of the services provided by the TTO (partly due to greater exposure to the TTO), female academics are likely to regard the resources provided as insufficient, suggesting they have the greater need for them. Similarly, and as discussed in the literature, female academics are more likely to "wait to be asked". Table 7 shows that female academics are more likely to say that commercial ventures resulted from mutual actions following a formal meeting, while male academics are more likely to mention own actions (which is equivalent to "asking"), or actions involving the TTO.

12 Our data shows that only $11 \%$ of female academics have previous experience of starting or running a small business, versus $16 \%$ of male academics. 
Table 7 Who makes the initial approach? (\% of those who have been involved in academic entrepreneurship, more than one may apply)

\begin{tabular}{llccr}
\hline & Male & Female & Difference & Z-value \\
\hline University office (e.g., TTO) & 23.7 & 20.7 & $3.0^{* * *}$ & 4.64 \\
External organisation & 75.3 & 74.8 & 0.5 & 0.69 \\
Own actions & 59.6 & 57.9 & $1.7^{* *}$ & 2.23 \\
Mutual actions following formal meeting & 57.0 & 59.3 & $-2.3 * * *$ & -3.11 \\
Mutual actions following informal meeting & 65.1 & 64.6 & 0.5 & 0.71 \\
\hline
\end{tabular}

Data from the Cambridge Centre for Business Research Survey of Knowledge Exchange Activity by United Kingdom Academics, 2005-2009 (see Abreu et al. 2009 for details). The Z-value corresponds to a difference in proportions test

Table 8 Changing role of commercial activities (\% who agree with the statement "over the past few years, universities have gone too far in attempting to meet the needs of industry to the detriment of their core teaching and research roles")

\begin{tabular}{lcccr}
\hline & Male & Female & Difference & Z-value \\
\hline Strongly agree & 12.8 & 10.0 & $2.8^{* * * *}$ & 6.40 \\
Somewhat agree & 31.0 & 30.3 & 0.7 & 1.03 \\
Neither agree nor disagree & 31.0 & 36.6 & $-5.6^{* * *}$ & -8.64 \\
Somewhat agree & 19.8 & 19.7 & 0.1 & 0.18 \\
Strongly disagree & 5.4 & 3.4 & $2.0^{* * *}$ & 6.97
\end{tabular}

Data from the Cambridge Centre for Business Research Survey of Knowledge Exchange Activity by United Kingdom Academics, 2005-2009 (see Abreu et al. 2009 for details). The Z-value corresponds to a difference in proportions test

Finally, we explore two of the psychological explanations proposed by the literature. Table 8 shows the percentage of male and female survey respondents who agree with the statement "over the past few years, universities have gone too far in attempting to meet the needs of industry to the detriment of their core teaching and research roles". Our aim was to test whether female academics are more ambivalent (or, alternatively, more negative) about research commercialisation, as highlighted by Murray and Graham (2007). Our findings support the ambivalence view, with male academics feeling more strongly (either for or against) on this issue, while female academics are significantly more likely to select "neither agree nor disagree". We do not, however, find evidence that female academics have more negative views on commercialisation.

Finally, we find that female academics are more likely to state that their research is of relevance to non-commercial organisations (as shown on Table 9), while male academics are more likely to state that it has been applied in a commercial setting, or that it is in an area of interest to industry/business. This may be because female academics are overrepresented in academic disciplines that are strongly associated with the public and not-forprofit sectors (such as the health sciences, social sciences, and humanities), and also partly because they feel more ambivalent about research commercialisation (as shown in Table 8), and are therefore more comfortable engaging with external organisations on a not-for-profit basis.

As a final step, we test whether the gender gap persists after controlling for a range of personal characteristics associated with academic entrepreneurship, as identified by the 
Table 9 Scope for commercialisation of research (\% who agree with the statement "my research...")

\begin{tabular}{lllrr}
\hline & Male & Female & Difference & Z-value \\
\hline Has been applied in a commercial setting & 21.4 & 10.4 & $11.0^{* * *}$ & 21.45 \\
Is in an area of interest to industry/business & 37.9 & 22.9 & $15.0^{* * *}$ & 23.60 \\
Has relevance for non-commercial organisations & 64.1 & 71.1 & $-7.0^{* * *}$ & -10.86 \\
Has not relevance for external organisations & 11.0 & 10.0 & $1.0^{* *}$ & 2.03 \\
\hline
\end{tabular}

Data from the Cambridge Centre for Business Research Survey of Knowledge Exchange Activity by United Kingdom Academics, 2005-2009 (see Abreu et al. 2009 for details). The Z-value corresponds to a difference in proportions test

literature. The variables included are those discussed in Sect. 4.3, and correspond to the factors explored in the descriptive analysis above. We estimate two probit models for spinout activity, one with only a female dummy variable as explanatory variable, and one that also includes the other determinants listed in Sect. 4.3. The results are shown in Table 10. As expected, the probit model with only the female dummy variable captures the difference in spinout activity between male and female academics, and is equivalent to the gender gap shown in Table 1 (3.2 percentage points). The second column shows the model with all of the explanatory variables included, in addition to the female dummy variable. The first result to note is that the coefficient of the female dummy variable is now much reduced, and is down to 0.8 percentage points. While this is not quite as dramatic a result as that found by Colyvas et al. (2012), it does indicate that a large proportion of the gender gap can be explained by differences in the explanatory variables. The remainder of the gender gap is then likely to be due to discrimination and other unknown factors, as we explore in the next section. The results for the other explanatory are also as expected. Being a professor raises the probability of spinout activity by 1.1 percentage points, relative to being a lecturer. Being involved in use-inspired research or applied research is associated with higher probabilities of spinout activity ( 0.7 and 0.8 percentage points, respectively), relative to being involved in basic research. The academic discipline also has an important effect on the outcome variables; academics in engineering and the physical sciences are more likely to be involved in spinouts (by 0.8 percentage points), while academics in the humanities, social sciences, and education are less likely to be (by 1.2, 1.2 and 1.0 percentage points). Being based at a top research university is associated with higher levels of engagement ( 0.4 percentage points), while having entrepreneurial experience has a substantial and positive effect (12.4 percentage points). Participating in networks with external partners is associated with a small increase in spinout activity (1.1 percentage points), ethical considerations only have a small effect, and the existence of perceived constraints has no statistically significant effect. These results are in keeping with the findings of the descriptive analysis, and indicate that although differences in the explanatory variables explain some of the gender gap, there is a component that remains unexplained.

\section{Disaggregating the gender gap}

As discussed above, the attributes of female and male academics tend to differ in several key ways. Female academics are more likely to work in academic disciplines for which there is less of a tradition of academic entrepreneurship, to hold more junior 
Table 10 Probit models for spinout activity, with female dummy variable

\begin{tabular}{|c|c|c|}
\hline & (1) & (2) \\
\hline Female & $\begin{array}{l}-0.032 * * * \\
(0.003)\end{array}$ & $\begin{array}{l}-0.008 \text { *** } \\
(0.002)\end{array}$ \\
\hline Professor & & $\begin{array}{l}0.011 * * * \\
(0.003)\end{array}$ \\
\hline Reader or senior lecturer & & $\begin{array}{l}0.002 \\
(0.002)\end{array}$ \\
\hline \multicolumn{3}{|l|}{ Lecturer $^{\dagger}$} \\
\hline Research fellow & & $\begin{array}{l}-0.003 \\
(0.002)\end{array}$ \\
\hline Research assistant & & $\begin{array}{l}0.003 \\
(0.005)\end{array}$ \\
\hline \multicolumn{3}{|l|}{ Basic research $^{\dagger}$} \\
\hline Use-inspired basic research & & $\begin{array}{l}0.007 * * * \\
(0.003)\end{array}$ \\
\hline Applied research & & $\begin{array}{l}0.008 * * * \\
(0.002)\end{array}$ \\
\hline Other type of research & & $\begin{array}{l}0.005 \\
(0.006)\end{array}$ \\
\hline Health sciences & & $\begin{array}{l}-0.004 * \\
(0.002)\end{array}$ \\
\hline \multicolumn{3}{|l|}{ Biological sciences $^{\dagger}$} \\
\hline Eng. and physical sciences & & $\begin{array}{l}0.008 * * * \\
(0.003)\end{array}$ \\
\hline Social sciences & & $\begin{array}{l}-0.012 * * * \\
(0.002)\end{array}$ \\
\hline Business and media & & $\begin{array}{l}-0.007 * * * \\
(0.002)\end{array}$ \\
\hline Humanities & & $\begin{array}{l}-0.012 * * * \\
(0.002)\end{array}$ \\
\hline Creative arts & & $\begin{array}{l}-0.006^{* *} \\
(0.002)\end{array}$ \\
\hline Education & & $\begin{array}{l}-0.010^{* * * *} \\
(0.002)\end{array}$ \\
\hline Top research university & & $\begin{array}{l}0.004 * * \\
(0.002)\end{array}$ \\
\hline Business experience & & $\begin{array}{l}0.124 * * * \\
(0.008)\end{array}$ \\
\hline Network participant & & $\begin{array}{l}0.011 * * * \\
(0.002)\end{array}$ \\
\hline Constraints: lack of time & & $\begin{array}{l}-0.001 \\
(0.002)\end{array}$ \\
\hline Constraints: no partners & & $\begin{array}{l}0.000 \\
(0.002)\end{array}$ \\
\hline Constraints: lack of interest & & $\begin{array}{l}0.000 \\
(0.003)\end{array}$ \\
\hline Ethics: too far & & $\begin{array}{l}-0.004^{* * * *} \\
(0.001)\end{array}$ \\
\hline Ethics: too little & & $\begin{array}{l}0.006 * * * \\
(0.002)\end{array}$ \\
\hline Observations & 17,278 & 17,278 \\
\hline Pseudo $\mathrm{R}^{2}$ & 0.026 & 0.284 \\
\hline
\end{tabular}

Data from the Cambridge Centre for Business Research Survey of Knowledge Exchange Activity by United Kingdom Academics, 2005-2009 (see Abreu et al. 2009 for details). Table reports marginal effects

$\dagger$ Omitted category; *** significant at $10 \%$; ** significant at 5\%;

* significant at $10 \%$ 
positions, to have smaller networks and therefore rely more on the TTO for their entrepreneurial activities, and to feel more ambivalent about the commercialisation of their research. Since these characteristics are also associated with lower rates of academic entrepreneurship, a useful question to ask is whether the observed differences in academic entrepreneurship between male and female academics are due to differences in the attributes, or to differences in the way that those attributes translate into academic entrepreneurship. We investigate this question for our main variable of interest, spinout activity, using the Blinder-Oaxaca decomposition method described in Sect. 4.2.

Table 11 shows the results of the decomposition, based on a model that includes the variables discussed in Sect. 4.3. As shown in the first line of Table 11, the overall gender gap in spinout activity is 3.3 percentage points, and this gap is statistically significant. The Blinder-Oaxaca decomposition shows that $61 \%$ of this gap can be explained by differences in the endowments, meaning that if female academics had the average attributes of the male academics in the sample, the gender gap would close by this amount. The part of the gender gap that can be explained by differences in the coefficients (the behavioural responses to those attributes), is $39 \%$. This can be interpreted as the degree to which the gap would close if the female academics in the sample had the coefficients of the male academics. This is often referred to as the "unexplained component", since it may partly indicate gender-based discrimination. We can disaggregate the gender gap further by looking at the decomposition for individual variables, as shown in the remainder of Table 11. The endowments that explain the greatest proportions of the gender gap are whether the individual is a professor (14\%), academic discipline, particularly engineering and the physical sciences (14\%), and whether the individual has previous experience in starting or running a small business (23\%). This implies that if female academics were as likely to be professors as the average male academic in the sample, the gap would close by $14 \%$, and similarly for the other two variables. Of particular interest is the large effect associated with previous experience, as it implies that less exposure to commercial activities leads to greater barriers to engagement in the future, resulting in a significant constraint to female academic entrepreneurship.

Few of the individual differences in the coefficients are statistically significant. One exception is the type of research, where the gender gap would increase if female academics responded to applied research in the same way as male academics do $(-25 \%)$, since working in applied research is more likely to lead to spinout activity for female academics. ${ }^{13}$ Another exception is academic discipline, where our results show that female academics in the health sciences would be more likely to engage in commercialisation if they had the same response as male academics do to being in that discipline (15.7\%). In other words, male academics in the health sciences are much more likely than female academics in the same discipline to generate spinouts, probably because female academics in the health sciences are more likely to be in sub-fields where there are fewer opportunities

\footnotetext{
13 Table 20 in Appendix shows probit models of spinout activity as a function of the explanatory variables discussed in Sect. 4.3, for male and female academics separately. These regressions form the basis for the Blinder-Oaxaca decomposition and can help us to interpret the results. For instance, the effect of type of research on spinout activity is greater (and more statistically significant) for female academics, after controlling for academic discipline. Since the effect of applied research is slightly less positive for male academics, the Blinder-Oaxaca decomposition results show that if female academics responded to applied research in the same way as male academics, they would engage in less spinout activity, which would result in a larger gender gap.
} 
Table 11 Oaxaca decomposition for spinout activity by gender

\begin{tabular}{|c|c|c|c|}
\hline & Coefficient & Standard error & Percentage \\
\hline Overall & 0.033 & 0.002 & \\
\hline Endowments & 0.020 & 0.001 & 61.3 \\
\hline Coefficients & 0.013 & 0.002 & 38.7 \\
\hline \multicolumn{4}{|l|}{ Differences in the endowments } \\
\hline Professor & $0.005 * * *$ & 0.001 & 13.7 \\
\hline Reader or senior lecturer & 0.000 & 0.000 & 0.0 \\
\hline \multicolumn{4}{|l|}{ Lecturer $^{\dagger}$} \\
\hline Research fellow & 0.001 & 0.001 & 1.7 \\
\hline Research assistant & 0.000 & 0.000 & -0.2 \\
\hline \multicolumn{4}{|l|}{ Basic research $^{\dagger}$} \\
\hline Use-inspired basic research & -0.000 & 0.000 & 0.8 \\
\hline Applied research & $-0.002 * * *$ & 0.001 & -5.0 \\
\hline Other type of research & 0.000 & 0.000 & 0.1 \\
\hline Health sciences & 0.000 & 0.001 & 1.2 \\
\hline \multicolumn{4}{|l|}{ Biological sciences $^{\dagger}$} \\
\hline Eng. and physical sciences & $0.005^{* * *}$ & 0.002 & 14.1 \\
\hline Social sciences & $0.002 * * *$ & 0.000 & 5.4 \\
\hline Business and media & $-0.000 * *$ & 0.000 & -1.1 \\
\hline Humanities & $0.001 * * *$ & 0.000 & 4.5 \\
\hline Creative arts & 0.000 & 0.000 & 0.0 \\
\hline Education & $0.002 * *$ & 0.001 & 4.7 \\
\hline Top research university & $0.001 * * *$ & 0.000 & 2.3 \\
\hline Business experience & $0.007 * * *$ & 0.000 & 22.6 \\
\hline Network participant & $-0.001 * * *$ & 0.000 & -2.4 \\
\hline Constraints: lack of time & -0.000 & 0.000 & -0.2 \\
\hline Constraints: no partners & 0.000 & 0.000 & 0.4 \\
\hline Constraints: lack of interest & 0.000 & 0.000 & 0.2 \\
\hline Ethics: too far & $-0.001 * * *$ & 0.000 & -1.7 \\
\hline Ethics: too little & $0.000 * * *$ & 0.000 & 0.0 \\
\hline \multicolumn{4}{|l|}{ Differences in the coefficients } \\
\hline Professor & -0.000 & 0.001 & -0.1 \\
\hline Reader or senior lecturer & -0.002 & 0.003 & -6.2 \\
\hline \multicolumn{4}{|l|}{ Lecturer $^{\dagger}$} \\
\hline Research fellow & 0.001 & 0.002 & 2.7 \\
\hline Research assistant & -0.001 & 0.001 & -1.5 \\
\hline \multicolumn{4}{|l|}{ Basic research $^{\dagger}$} \\
\hline Use-inspired basic research & -0.005 & 0.003 & -14.2 \\
\hline Applied research & $-0.008 *$ & 0.005 & -25.3 \\
\hline Other type of research & $-0.001 *$ & 0.001 & -4.3 \\
\hline Health sciences & $0.005^{*}$ & 0.003 & 15.7 \\
\hline \multicolumn{4}{|l|}{ Biological sciences ${ }^{\dagger}$} \\
\hline Eng. and physical sciences & 0.001 & 0.001 & 1.7 \\
\hline
\end{tabular}


Table 11 continued

\begin{tabular}{lllr}
\hline & Coefficient & Standard error & Percentage \\
\hline Social sciences & -0.003 & 0.003 & -10.5 \\
Business and media & 0.000 & 0.001 & 0.3 \\
Humanities & 0.002 & 0.002 & 6.8 \\
Creative arts & 0.000 & 0.001 & 1.4 \\
Education & 0.002 & 0.001 & 6.1 \\
Top research university & 0.003 & 0.003 & 9.4 \\
Business experience & 0.002 & 0.001 & 5.0 \\
Network participant & -0.002 & 0.006 & -6.8 \\
Constraints: lack of time & 0.006 & 0.004 & 19.1 \\
Constraints: no partners & 0.001 & 0.001 & 2.9 \\
Constraints: lack of interest & 0.000 & 0.001 & 0.7 \\
Ethics: too far & -0.004 & 0.003 & -11.7 \\
Ethics: too little & 0.002 & 0.002 & 0.0 \\
Observations & 18,975 & & \\
\hline
\end{tabular}

Data from the Cambridge Centre for Business Research Survey of Knowledge Exchange Activity by United Kingdom Academics, 2005-2009 (see Abreu et al. 2009 for details)

$\dagger$ Omitted category; $* * *$ significant at $1 \%$; ** significant at $5 \%$; $*$ significant at $1 \%$

for research commercialisation. This is after controlling for academic position, experience and other variables.

As discussed in Sect. 4.2, however, the results of the Blinder-Oaxaca decomposition are likely to be biased if there are few (or no) females in the sample with the same attributes as those of the males in the sample. In order to address this, we use the Nopo decomposition approach outlined in Sect. 4.2, and the results are shown in Table 12. In order to interpret the results, we express the gender gap as a percentage of the female spinout rate. The overall gender gap is $207 \%$. This can be decomposed into a component that is due to differences in the individual attributes for individuals that can be matched to the other group (31\%), a component that is due to differences in the coefficients, and is therefore "unexplained" (76\%), a component explained by differences between males who have attributes that cannot be matched to those of the females in the sample, and males with attributes that can be matched (114\%), and a component explained by differences between females with attributes that can be matched to the males in the sample, and attributes that cannot be matched $(-14 \%)$. Our results therefore indicate that the majority of the gender gap can be explained by characteristics of male academics (seniority, type of research, discipline, experience) that are highly conducive to successful commercialisation, but which are very rare among female academics. After this, the second most important component is differences in the behavioural responses of female academics, or the "unexplained component". Our results therefore indicate the existence of significant differences in the characteristics of female and male academics, which in turn translate into substantially different rates of academic entrepreneurship. 
Table 12 Non-parametric Nopo (2008) decomposition for spinout activity by gender (\%)

\begin{tabular}{|c|c|c|}
\hline Component & Description & Percentage \\
\hline$D$ & Overall gender gap (as \% of female spinout rate) & 207.1 \\
\hline$M$ & $\begin{array}{l}\text { Part explained by differences between two groups of } \\
\text { males, those who have characteristics that cannot be } \\
\text { matched to female characteristics, and those who have } \\
\text { characteristics that can be matched }\end{array}$ & 114.3 \\
\hline$X$ & $\begin{array}{l}\text { Part explained by differences in the distribution of } \\
\text { characteristics of males and females over the common } \\
\text { support }\end{array}$ & 30.7 \\
\hline$F$ & $\begin{array}{l}\text { Part explained by differences between two groups of } \\
\text { females, those who have characteristics that can be } \\
\text { matched to male characteristics, and those who have } \\
\text { characteristics that cannot be matched }\end{array}$ & -13.8 \\
\hline$D_{O}$ & $\begin{array}{l}\text { Unexplained component, not attributable to differences } \\
\text { in individual characteristics }\end{array}$ & 75.8 \\
\hline Unexplained component & & 75.8 \\
\hline $\begin{array}{l}\text { Explained by individual } \\
\text { characteristics over the common } \\
\text { support }\end{array}$ & & 30.7 \\
\hline $\begin{array}{l}\text { Explained by differences in the } \\
\text { supports }\end{array}$ & & 100.5 \\
\hline$\%$ of males matched & & 61.7 \\
\hline$\%$ of females matched & & 74.1 \\
\hline Observations & & 18,975 \\
\hline
\end{tabular}

Data from the Cambridge Centre for Business Research Survey of Knowledge Exchange Activity by United Kingdom Academics, 2005-2009 (see Abreu et al. 2009 for details). The variables used in the matching procedure are: academic position (Professor, Reader or Senior Lecturer, Lecturer, Research Fellow), type of research (basic, use-inspired basic, applied), academic discipline (health sciences, biological sciences, engineering and physical sciences, social sciences, business and media, humanities, creative arts, Education), top research university, business experience, network participant, constraints (lack of time, no partners, lack of interest), and ethics (too far, too little)

\section{Conclusions}

Our study analyses the determinants of the gender gap in academic entrepreneurship among UK-based academics from across a wide range of academic disciplines. We focus on spinout activity as a measure of academic entrepreneurship, as it is an easily quantifiable measure, which is appropriate for academics working in the sciences, social sciences, humanities and the arts. We explore the relevance of the different explanations that have been identified in the literature, and show that the average female academic in our sample differs from the average male academic in several important ways. Female academics are likely to hold less senior positions, to work in the health sciences, social sciences, humanities and education, to have less prior experience of running a business, and to feel ambivalent about research commercialisation.

All of these characteristics are also correlated with lower rates of academic entrepreneurship, and our Blinder-Oaxaca decomposition analysis shows that these differences in attributes translate into substantial differences in spinout activity. We control for the possibility of selection bias by using the non-parametric Nopo (2008) matching 
model, which allows for differences in the distribution of these attributes across male and female academics. Our results indicate that for certain combinations of characteristics that are more prevalent among male academics (being a professor, working on use-inspired basic research, in engineering and the physical sciences, with previous entrepreneurial experience, with positive views on the ethics of commercialisation) there are few or no female academics with the same mix of characteristics. This in turn explains a substantial part of the entrepreneurship gender gap.

In the current policy context, our results have several important implications. First, we find that while female academics face significant obstacles to commercialising their research, this does not necessarily imply that the gender gap will close once these obstacles are removed. Female academics differ from their male counterparts in several important ways, at least some of which may be due to conscious choices, such as self-selection into research areas that are more conducive to links with the public and not-for-profit sectors. Rather than impose a one-size-fits-all policy, TTOs should adapt to support ventures that differ from the traditional science-based commercial venture.

Second, female academics are severely constrained in their opportunities for commercialisation by their less senior status, and lack of entrepreneurial experience. There is scope for universities to support female academics by improving their career progression opportunities, in a way that is flexible and compatible with family life. Shadowing schemes and networking events would help to close the gender gap in this context.

Finally, we have shown that the gender gap in academic entrepreneurship exists across the entire range of academic disciplines, and is not solely confined to the sciences. Greater visibility of the entrepreneurial activities in areas other than engineering and the life sciences would help to highlight the specific obstacles faced by female academics working in these fields. More research is also needed to understand the specific constraints faced by female academics in disciplines other than the sciences and engineering.

Open Access This article is distributed under the terms of the Creative Commons Attribution 4.0 International License (http://creativecommons.org/licenses/by/4.0/), which permits unrestricted use, distribution, and reproduction in any medium, provided you give appropriate credit to the original author(s) and the source, provide a link to the Creative Commons license, and indicate if changes were made.

\section{Appendix}

See Tables 13, 14, 15, 16, 17, 18, 19 and 20.

Table 13 Comparison of survey sample and population by academic position ( $\%$ of the total for all positions)

\begin{tabular}{lcc}
\hline & Sample & Population \\
\hline Professor & 20.9 & 12.5 \\
Reader or Senior Lecturer & 32.9 & 25.6 \\
Lecturer & 24.3 & 35.6 \\
Research Associate or Assistant & 21.9 & 26.3 \\
All disciplines & 100.00 & 100.0 \\
\hline
\end{tabular}

Survey sample data from the Cambridge Centre for Business Research Survey of Knowledge Exchange Activity by United Kingdom Academics, 2005-2009 (see Abreu et al. 2009 for details). Population data are from the Resources of Higher Education Institutions 2007/08, Table 12, Higher Education Statistics Agency (HESA), available from www.hesa.ac.uk 
Table 14 Comparison of survey sample and population by academic position, percentage of female academics (\% of the total for each position)

\begin{tabular}{lllll}
\hline & $\begin{array}{l}\text { \% female } \\
\text { in sample }\end{array}$ & $\begin{array}{l}\text { \% female } \\
\text { in population }\end{array}$ & $\begin{array}{l}\text { Male/female } \\
\text { in sample }\end{array}$ & $\begin{array}{l}\text { Male/female } \\
\text { in population }\end{array}$ \\
\hline Professor & 22.38 & 18.61 & 4.4 & 3.5 \\
Reader or senior lecturer & 40.04 & 38.42 & 1.6 & 1.5 \\
Lecturer & 47.42 & 47.71 & 1.1 & 1.1 \\
Research associate or assistant & 48.41 & 45.83 & 1.2 & 1.1 \\
\hline
\end{tabular}

Survey sample data from the Cambridge Centre for Business Research Survey of Knowledge Exchange Activity by United Kingdom Academics, 2005-2009 (see Abreu et al. 2009 for details). Population data are from the Resources of Higher Education Institutions 2007/08, Table 12, Higher Education Statistics Agency (HESA), available from www.hesa.ac.uk

Table 15 Comparison of survey sample and population by discipline (\% of the total for all disciplines)

\begin{tabular}{lrr}
\hline & Sample & Population \\
\hline Health sciences & 22.46 & 17.03 \\
Biological sciences & 7.71 & 9.89 \\
Eng. and physical sciences & 25.00 & 22.84 \\
Social sciences & 16.06 & 22.56 \\
Business and media & 10.03 & 7.61 \\
Humanities & 11.87 & 12.37 \\
Creative arts & 3.38 & 3.68 \\
Education & 3.49 & 4.02 \\
All disciplines & 100.00 & 100.0 \\
\hline
\end{tabular}

Survey sample data from the Cambridge Centre for Business Research Survey of Knowledge Exchange Activity by United Kingdom Academics, 2005-2009 (see Abreu et al. 2009 for details). Population data are from the Resources of Higher Education Institutions 2007/08, Table 12, Higher Education Statistics Agency (HESA), available from www.hesa.ac.uk

Table 16 Comparison of survey sample and population by discipline, percentage of female academics $(\%$ of the total for each discipline)

\begin{tabular}{lcccc}
\hline & $\begin{array}{l}\text { \% female } \\
\text { in sample }\end{array}$ & $\begin{array}{l}\text { \% female } \\
\text { in population }\end{array}$ & $\begin{array}{l}\text { Male/female } \\
\text { in sample }\end{array}$ & $\begin{array}{l}\text { Male/female } \\
\text { in population }\end{array}$ \\
\hline Health sciences & 31.6 & 25.3 & 3.0 & 2.2 \\
Biological sciences & 19.4 & 14.5 & 5.9 & 4.2 \\
Eng. and physical sciences & 7.3 & 6.6 & 14.2 & 12.6 \\
Social sciences & 26.7 & 21.0 & 3.8 & 2.8 \\
Business and media & 21.2 & 17.0 & 4.9 & 3.7 \\
Humanities & 26.1 & 23.3 & 3.3 & 2.8 \\
Creative arts & 25.7 & 24.8 & 3.0 & 2.9 \\
Education & 40.1 & 41.6 & 1.4 & 1.5 \\
\hline
\end{tabular}

Survey sample data from the Cambridge Centre for Business Research Survey of Knowledge Exchange Activity by United Kingdom Academics, 2005-2009 (see Abreu et al. 2009 for details). Population data are from the Resources of Higher Education Institutions 2007/08, Table 12, Higher Education Statistics Agency (HESA), available from www.hesa.ac.uk 


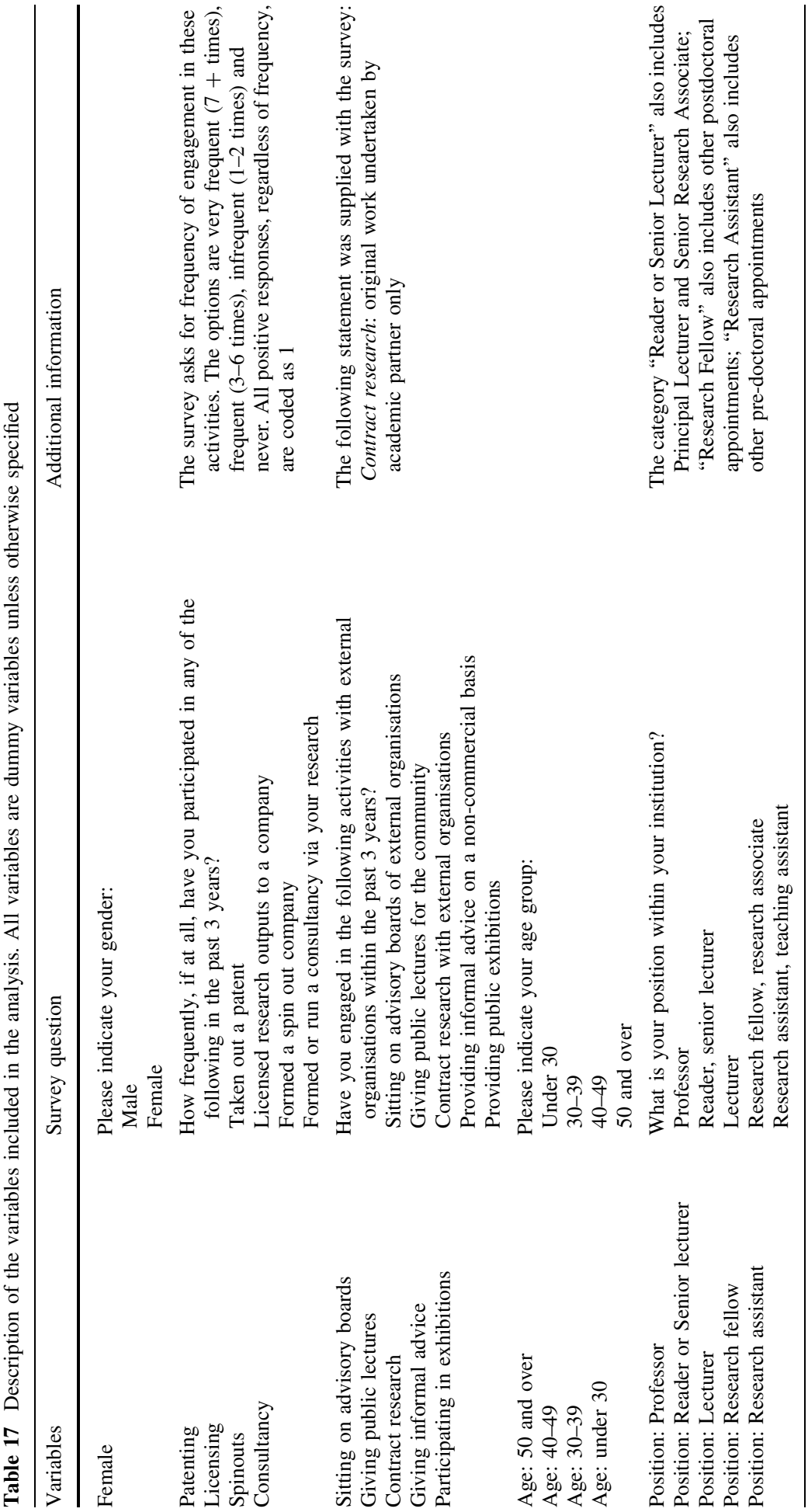




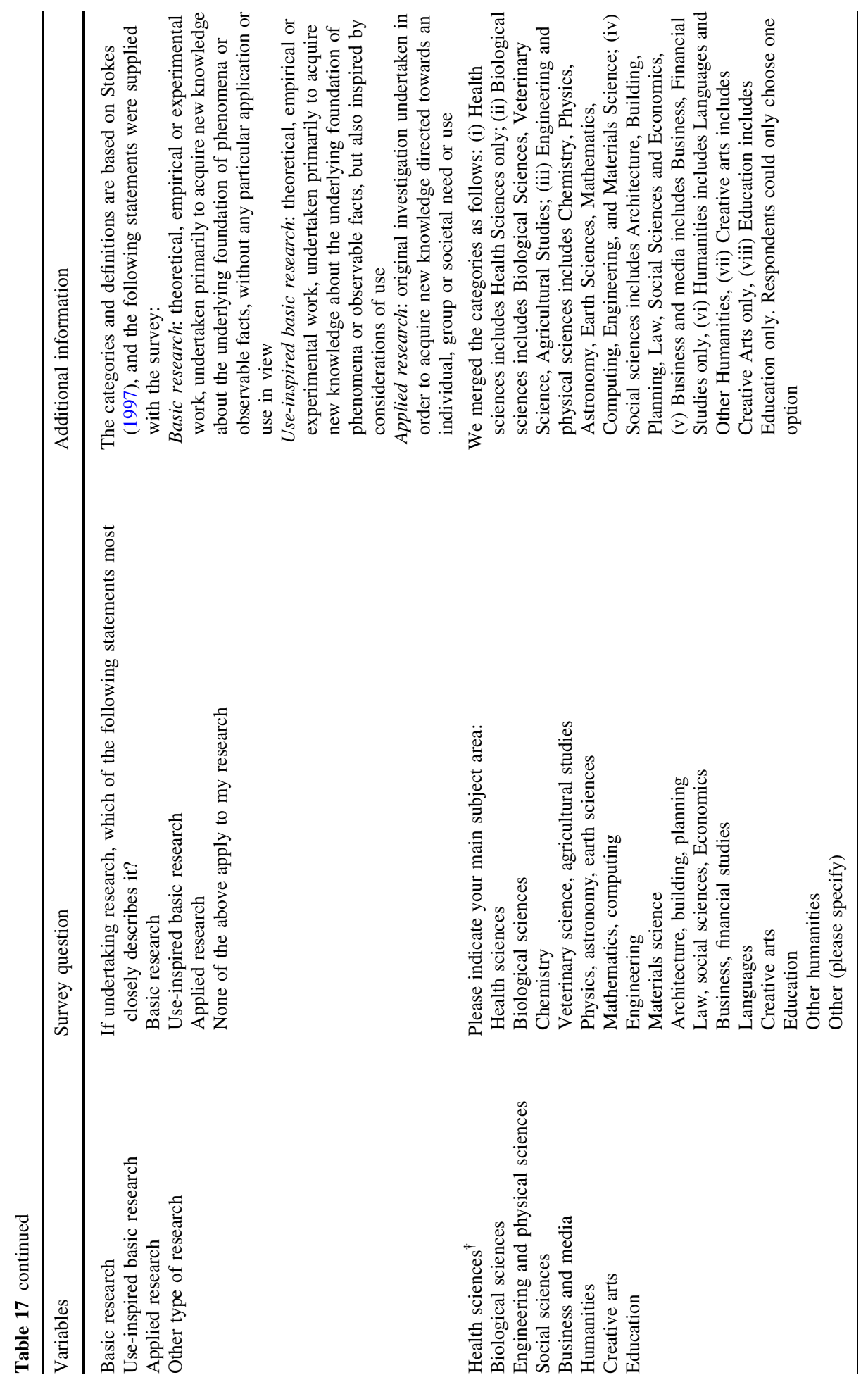




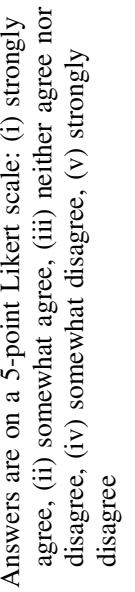

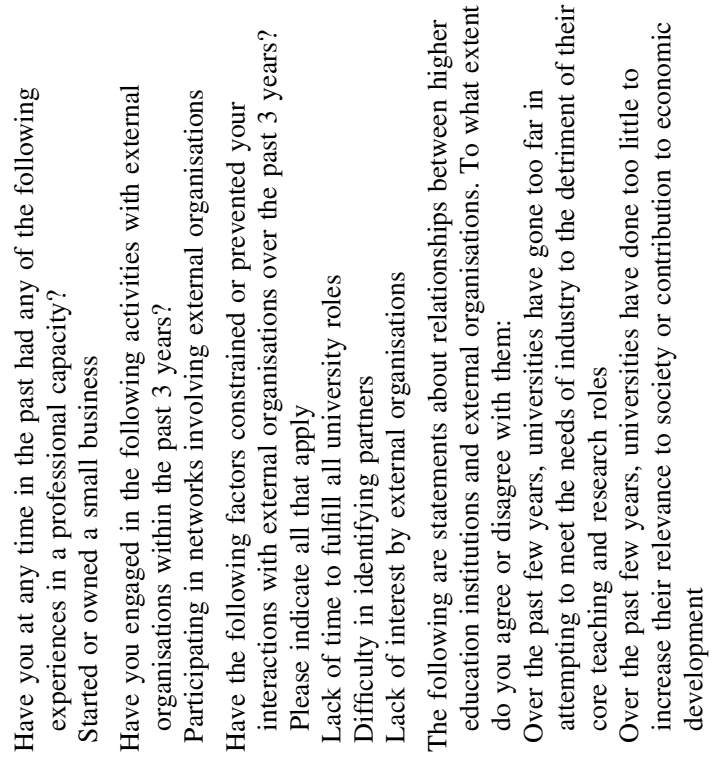

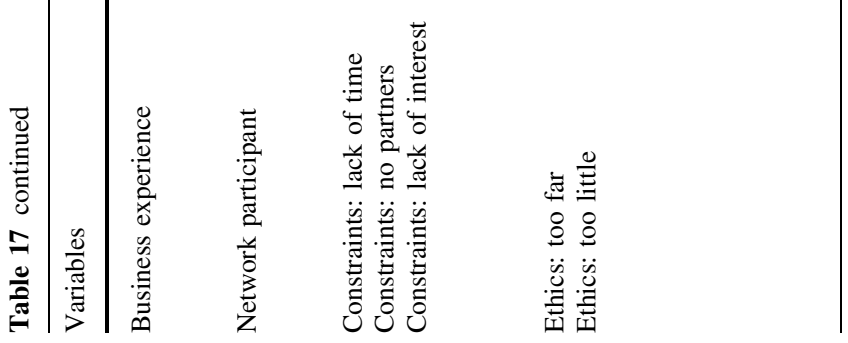




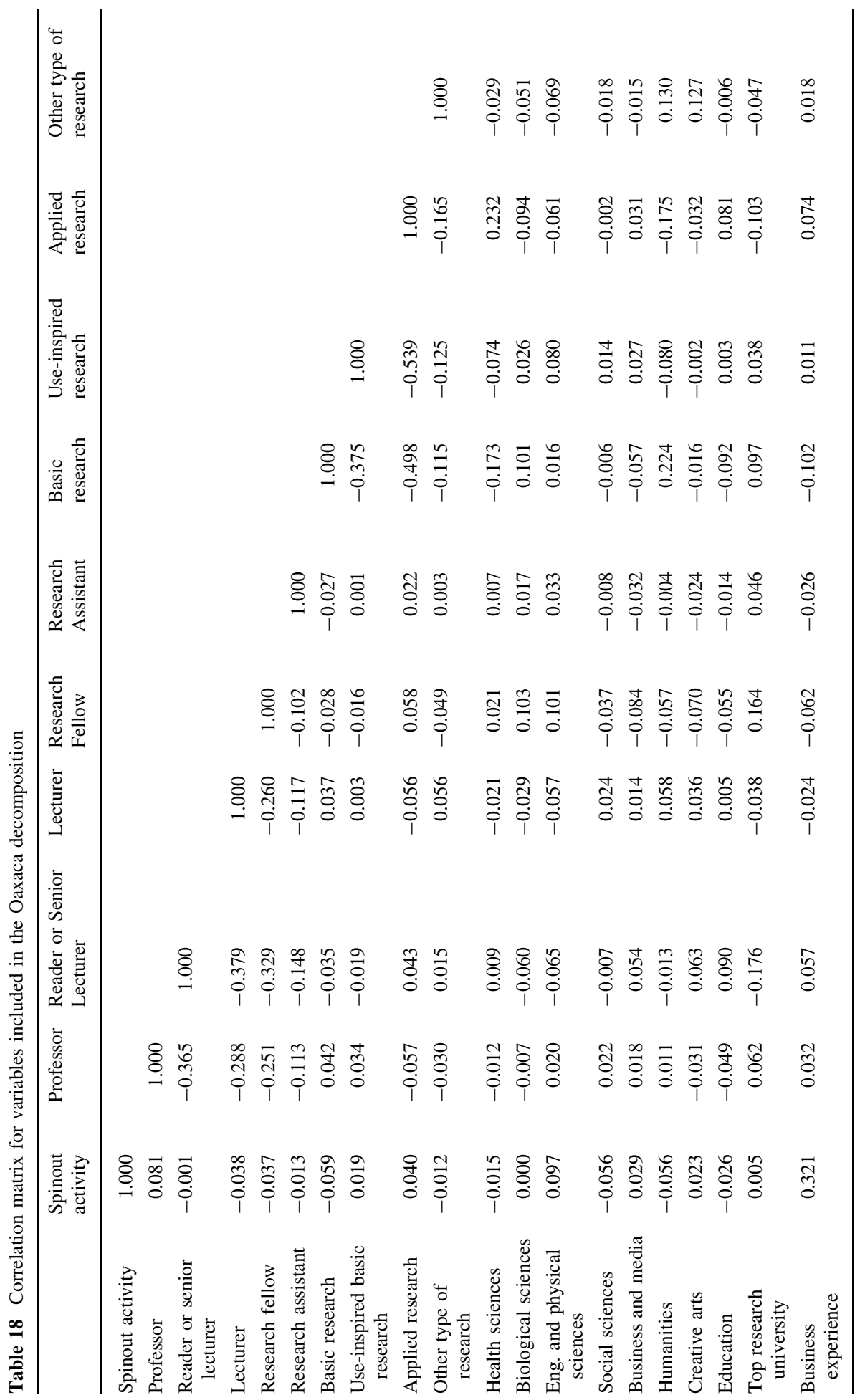




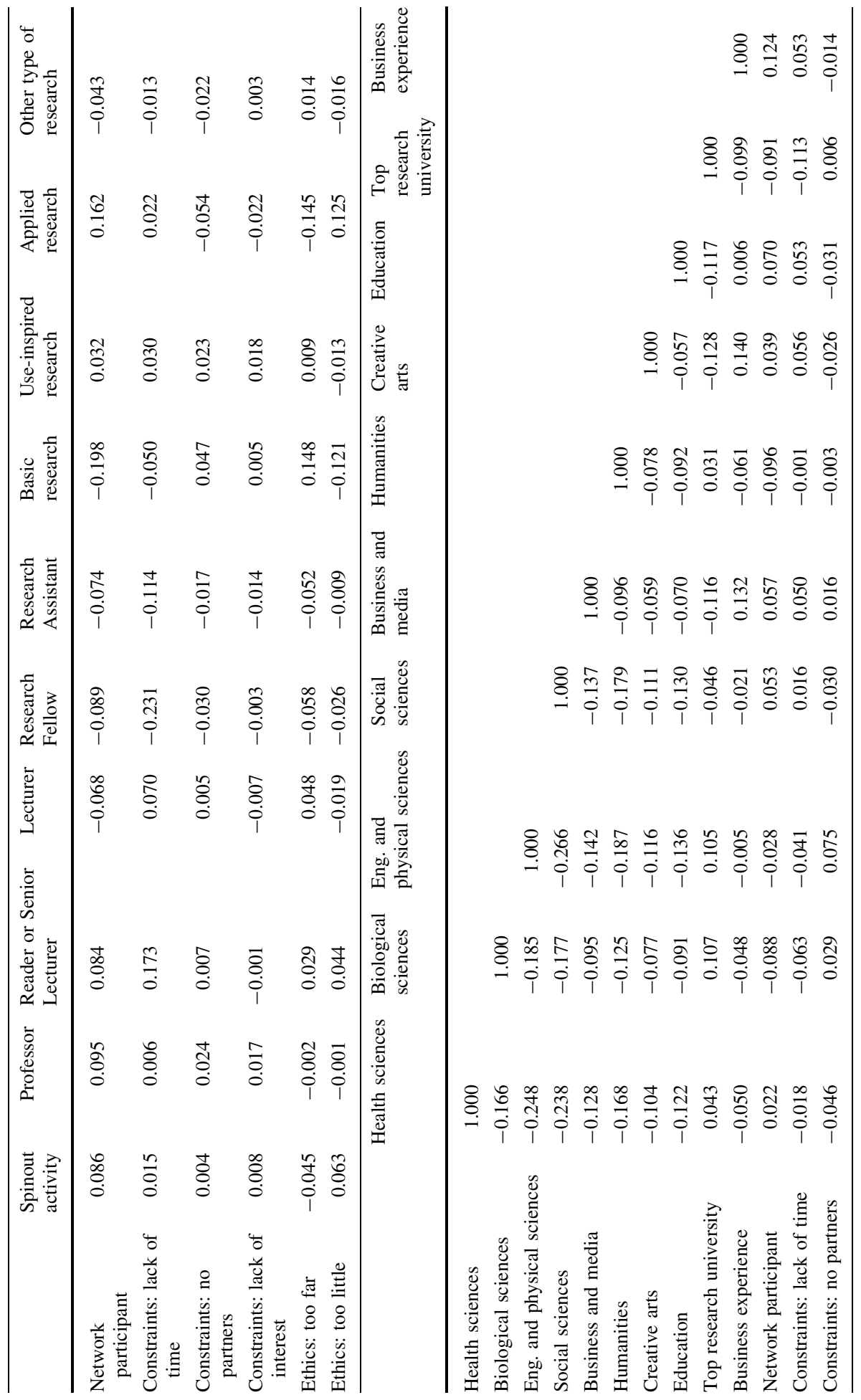




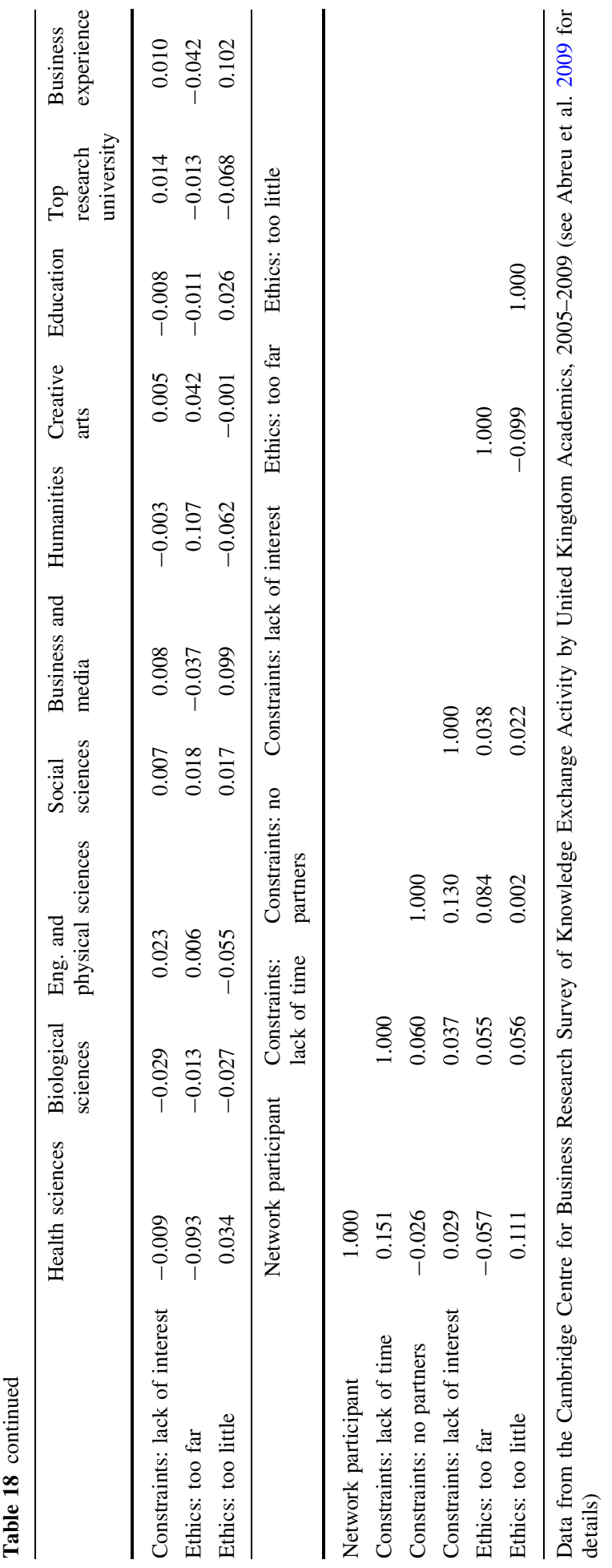


Table 19 Correlation matrix for academic position and age group variables

\begin{tabular}{lccrcc}
\hline & Professor & Reader or senior lecturer & Lecturer & Research fellow & Research assistant \\
\hline Age: under 30 & -0.131 & -0.167 & 0.001 & 0.186 & 0.296 \\
Age: 30-39 & -0.286 & -0.155 & 0.198 & 0.259 & 0.032 \\
Age: 40-49 & -0.050 & 0.163 & -0.004 & -0.108 & -0.067 \\
Age: 50 and over & 0.373 & 0.071 & -0.179 & -0.228 & -0.112 \\
\hline
\end{tabular}

Data from the Cambridge Centre for Business Research Survey of Knowledge Exchange Activity by United Kingdom Academics, 2005-2009 (see Abreu et al. 2009 for details)

Table 20 Probit models for spinout activity, for male and female academics

\begin{tabular}{|c|c|c|}
\hline & Male & Female \\
\hline Professor & $\begin{array}{l}0.014 * * * \\
(0.004)\end{array}$ & $\begin{array}{l}0.006 * * \\
(0.004)\end{array}$ \\
\hline Reader or senior lecturer & $\begin{array}{l}0.001 \\
(0.003)\end{array}$ & $\begin{array}{l}0.002 \\
(0.002)\end{array}$ \\
\hline \multicolumn{3}{|l|}{ Lecturer $^{\dagger}$} \\
\hline Research fellow & $\begin{array}{l}-0.003 \\
(0.004)\end{array}$ & $\begin{array}{l}-0.002 \\
(0.002)\end{array}$ \\
\hline Research assistant & $\begin{array}{l}0.001 \\
(0.007)\end{array}$ & $\begin{array}{l}0.004 \\
(0.005)\end{array}$ \\
\hline \multicolumn{3}{|l|}{ Basic research $^{\dagger}$} \\
\hline Use-inspired basic research & $\begin{array}{l}0.006 \\
(0.004)\end{array}$ & $\begin{array}{l}0.009 * * \\
(0.005)\end{array}$ \\
\hline Applied research & $\begin{array}{l}0.008 * * \\
(0.004)\end{array}$ & $\begin{array}{l}0.009 * * * \\
(0.004)\end{array}$ \\
\hline Other type of research & $\begin{array}{l}-0.001 \\
(0.007)\end{array}$ & $\begin{array}{l}0.017 * * \\
(0.013)\end{array}$ \\
\hline Health sciences & $\begin{array}{l}-0.001 \\
(0.004)\end{array}$ & $\begin{array}{l}-0.005 * * \\
(0.002)\end{array}$ \\
\hline \multicolumn{3}{|l|}{ Biological sciences $^{\dagger}$} \\
\hline Eng. and physical sciences & $\begin{array}{l}0.012 * * * \\
(0.005)\end{array}$ & $\begin{array}{l}0.003 \\
(0.004)\end{array}$ \\
\hline Social sciences & $\begin{array}{l}-0.019 * * * \\
(0.003)\end{array}$ & $\begin{array}{l}-0.005^{* *} \\
(0.002)\end{array}$ \\
\hline Business and media & $\begin{array}{l}-0.010 * * \\
(0.003)\end{array}$ & $\begin{array}{l}-0.004 \\
(0.002)\end{array}$ \\
\hline Humanities & $\begin{array}{l}-0.016 * * * \\
(0.003)\end{array}$ & $\begin{array}{l}-0.007 * * * \\
(0.001)\end{array}$ \\
\hline Creative arts & $\begin{array}{l}-0.007 \\
(0.004)\end{array}$ & $\begin{array}{l}-0.004 \\
(0.002)\end{array}$ \\
\hline Education & $\begin{array}{l}-0.012 * * \\
(0.003)\end{array}$ & $\begin{array}{l}-0.007 \text { *** } \\
(0.001)\end{array}$ \\
\hline Top research university & $\begin{array}{l}0.006 * * * \\
(0.002)\end{array}$ & $\begin{array}{l}0.000 \\
(0.002)\end{array}$ \\
\hline Business experience & $\begin{array}{l}0.164 * * * \\
(0.011)\end{array}$ & $\begin{array}{l}0.060 * * * \\
(0.010)\end{array}$ \\
\hline
\end{tabular}


Table 20 continued

\begin{tabular}{lll}
\hline & Male & Female \\
\hline Network participant & $0.015^{* * * *}$ & $0.006^{* * *}$ \\
& $(0.002)$ & $(0.002)$ \\
Constraints: lack of time & -0.001 & -0.003 \\
& $(0.002)$ & $(0.002)$ \\
Constraints: no partners & 0.001 & -0.001 \\
& $(0.003)$ & $(0.002)$ \\
Constraints: lack of interest & 0.001 & -0.001 \\
& $(0.004)$ & $(0.003)$ \\
Ethics: too far & $-0.008^{* * * *}$ & -0.000 \\
& $(0.002)$ & $(0.002)$ \\
Ethics: too little & $0.010 * * *$ & 0.001 \\
& $(0.003)$ & $(0.002)$ \\
Observations & 10,461 & 17,278 \\
Pseudo R & 0.287 & 0.284 \\
\hline
\end{tabular}

Data from the Cambridge Centre for Business Research Survey of Knowledge Exchange Activity by United Kingdom Academics, 2005-2009 (see Abreu et al. 2009 for details). Table reports marginal effects

$\dagger$ Omitted category; *** significant at $1 \%$; ** significant at $5 \%$; significant at $1 \%$

\section{References}

Abreu, M., \& Grinevich, V. (2013). The nature of academic entrepreneurship in the UK: Widening the focus on entrepreneurial activities. Research Policy, 42(2), 408-422.

Abreu, M., \& Grinevich, V. (2014). Academic entrepreneurship in the creative arts. Environment and Planning C: Government and Policy, 32(3), 451-470.

Abreu, M., Grinevich, V., Hughes, A., \& Kitson, M. (2009). Knowledge exchange between academics and the business, public and third sectors. London: UK Innovation Research Centre, University of Cambridge and Imperial College London.

Agrawal, A., \& Henderson, R. (2002). Putting patents in context: Exploring knowledge transfer from MIT. Management Science, 48(1), 44-60.

Blinder, A. S. (1973). Wage discrimination: Reduced form and structural estimates. Journal of Human Resources, 8, 436-455.

Borghans, L., Heckman, J. J., Golsteyn, B. H., \& Meijers, H. (2009). Gender differences in risk aversion and ambiguity aversion. Journal of the European Economic Association, 7(2-3), 649-658.

Carayol, N. (2007). Academic incentives, research organization and patenting at a large French University. Economics of Innovation and New Technology, 16, 119-138.

Cole, J. R., \& Zuckerman, H. (1984). The productivity puzzle: Persistence and change in patterns of publication of men and women scientists. In P. Maehr \& M. W. Steinkamp (Eds.), Advances in motivation and achievement (pp. 217-258). Greenwich, CT: JAI Press.

Colyvas, J. A., Snellman, K., Bercovitz, J., \& Feldman, M. (2012). Disentangling effort and performance: A renewed look at gender differences in commercializing medical school research. Journal of Technology Transfer, 37(4), 478-489.

Croson, R., \& Gneezy, U. (2009). Gender differences in preferences. Journal of Economic Literature, 47(2), 448-474.

Ding, W. W., Murray, F., \& Stuart, T. E. (2006). Gender differences in patenting in the academic life sciences. Science, 313, 665-667.

Eckel, C. C., \& Grossman, P. J. (2008). Men, women and risk aversion: Experimental evidence. Handbook of Experimental Economics Results, 1, 1061-1073.

Goel, R. K., Göktepe-Hultén, D., \& Ram, R. (2015). Academics' entrepreneurship propensities and gender differences. Journal of Technology Transfer, 40(1), 161-177. 
Haeussler, C., \& Colyvas, J. A. (2011). Breaking the ivory tower: Academic entrepreneurship in the life sciences in UK and Germany. Research Policy, 40(1), 41-54.

Levin, S. G., \& Stephan, P. E. (1991). Research productivity over the life cycle: Evidence for academic scientists. American Economic Review, 81, 114-132.

Link, A. N., Siegel, D. S., \& Bozeman, B. (2007). An empirical analysis of the propensity of academics to engage in informal university technology transfer. Industrial and Corporate Change, 16, 641-655.

Long, J. S. (1992). Measures of sex differences in scientific productivity. Social Forces, 71(1), 159-178.

Murray, F. (2002). Innovation as co-evolution of scientific and technological networks: Exploring tissue engineering. Research Policy, 31, 1389-1403.

Murray, F. (2004). The role of inventors in knowledge transfer: Sharing in the laboratory life. Research Policy, 33(4), 643-659.

Murray, F., \& Graham, L. (2007). Buying science and selling science: Gender differences in the market for commercial science. Industrial and Corporate Change, 16, 657-689.

Ñopo, H. (2008). Matching as a tool to decompose wage gaps. Review of Economics and Statistics, 90(2), 290-299.

Oaxaca, R. (1973). Male-female wage differentials in urban labor markets. International Economic Review, 14, 693-709.

Owen-Smith, J., \& Powell, W. W. (2001). To patent or not: Faculty decisions and institutional success at technology transfer. Journal of Technology Transfer, 26, 99-114.

Rosa, P., \& Dawson, A. (2006). Gender and the commercialization of university science: Academic founders of spinout companies. Entrepreneurship and Regional Development, 18(4), 341-366.

Siegel, D. S., Waldman, D. A., \& Link, A. N. (2003). Assessing the impact of organizational practices on the productivity of university technology transfer offices: An exploratory study. Research Policy, 32, $27-48$.

Siegel, D. S., Veugelers, R., \& Wright, M. (2007). Technology transfer offices and commercialization of university intellectual property: Performance and policy implications. Oxford Review of Economic Policy, 23(4), 640-660.

Stephan, P. E., \& El-Ganainy, A. (2007). The entrepreneurial puzzle: Explaining the gender gap. Journal of Technology Transfer, 32, 475-487.

Stephan, P. E., Gurmu, S., Sumell, A., \& Black, G. (2007). Who's patenting in the university? Evidence from a survey of doctorate recipients. Economics of Innovation and New Technology, 16(2), 71-99.

Stokes, D. E. (1997). Pasteurs quadrant: Basic science and technological innovation. Washington, DC: Brookings Institution Press.

Thursby, J. G., \& Thursby, M. C. (2005). Gender patterns of research and licensing activity of science and engineering faculty. Journal of Technology Transfer, 30, 343-353.

Whittington, K. B., \& Smith-Doerr, L. (2005). Gender and commercial science: Women's patenting in the life sciences. Journal of Technology Transfer, 30(4), 355-370.

Xie, Y., \& Shauman, K. A. (2003). Women in science: Career processes and outcomes (Vol. 26, No. 73.4). Cambridge, MA: Harvard University Press. 